Article

\title{
Local Users and Other Stakeholders' Perceptions of the Identification and Prioritization of Ecosystem Services in Fragile Mountains: A Case Study of Chure Region of Nepal
}

\author{
Ram Prasad Acharya ${ }^{\circledR}$, Tek Narayan Maraseni * and Geoff Cockfield \\ Centre for Sustainable Agricultural Systems, University of Southern Queensland, Queensland 4350, Australia; \\ RamPrasad.Acharya@usq.edu.au (R.P.A.); Geoff.Cockfield@usq.edu.au (G.C.) \\ * Correspondence: Tek.Maraseni@usq.edu.au
}

Received: 4 May 2019; Accepted: 14 May 2019; Published: 15 May 2019

\begin{abstract}
Forest-based ecosystem services (ES) play a vital role in improving people's livelihoods, the environment, and the economy. Prior studies have focused on technical aspects of economic valuation such as biophysical quantification through modeling and mapping, or monetary valuation, while little attention has been paid to the social dimensions. Taking case studies of two dominant community-based forest management systems (community forestry $-\mathrm{CF}$ and collaborative forestry-CFM) in the Chure region of Nepal, we investigate how local users and other stakeholders perceive the valuation of forest-based ecosystem services based on proximity (nearby vs. distant users), socio-economic class (rich vs. poor users), and forest management modalities (CF vs. CFM). We found that local users and other stakeholders in the Chure region identified a total of 42 forest-based ecosystem services: 16 provisioning, 15 regulating, and 11 cultural services. While all local users prioritised firewood, water quality improvement, and bequest values as the top three services, genetic resources, hazard protection, and hunting services were valued as having the lowest priority. The priorities placed on other services varied in many respects. For instance, rich users living near a CF showed a strong preference for fodder, grasses, and soil conservation services whereas users living far from forests prioritised timber, fresh water, and flood control services. In the case of CFM, rich users adjacent to forests preferred timber, soil conservation, and carbon sequestration services but those living far from forests chose timber, poles, and flood control as their top priorities. Differences in rankings also occurred among the regional managers, national experts, and forest users. The reasons for these differences and their policy implications are discussed, and ways of reaching consensus between the users are suggested.
\end{abstract}

Keywords: forests; valuation; community-based forest management

\section{Introduction}

The concept of ecosystem services (ES) first appeared in the 1980s [1] and gained increased recognition following a seminal paper by Costanza and his team [2]. Costanza et al. [2] first estimated the worth of the world's ES at US \$33 trillion, almost 1.2 times more than the total global gross domestic product in 1995. In their 2014 update, this estimate increased to US \$145 trillion [3]. Other groundbreaking works on ES include the Millennium Ecosystem Assessment in 2005 [4] and The Economics of Ecosystem and Biodiversity (TEEB) [5]. The concept of ES has now entered the discourse of many disciplines including natural resource management, biodiversity conservation, and environmental policy and accounting $[1,6]$. 
Forest-based ES play a vital role in enriching people's livelihoods, enhancing the environment, and developing the economy [7,8]. Valuation research in forest-based ES increased at an exponential rate from 2014 onwards [9,10]. Prior studies explored how forest-based ES contribute to generate value or benefits for people's livelihoods [11,12], the environment, and the economy [13]. However, these studies were constrained by their disproportionate focus on the technical aspects of economic valuation such as biophysical quantification through modelling and mapping [14-17], or by employing purely monetary valuation, of the forest-based ES [18-21]. Little research has been carried out that demonstrates how social dimensions, for example people's perceptions or preferences, affect or play important roles in the identification and prioritization of forest-based ES. Studies have called for urgent action to incorporate the views of broader stakeholders when carrying out forest-based ES valuation research [22-26].

The forest-based ES contribute in both developed and developing nations, although their contributions vary. The contribution to the livelihood of resource-poor rural people, particularly those in developing countries, is critically important [27,28]. Recent statistics show that forest-based ES provide approximately $20 \%$ of the income of rural households both through cash and by meeting subsistence needs [29]. About 75\% of poor people in developing countries are heavily dependent on forest-based ES [8]. However, despite their significant contributions to large populations, the actual social contributions of forest-based ES to different categories of users have not been adequately assessed.

The community based forest management (CBFM) system is the dominant forest management regime in developing countries. In this system, local people play a vital role in planning, decision-making, implementation, and benefit sharing [30,31]. About 511 million hectares of global forests (almost $15.5 \%$ ) are either owned or managed by such communities [32]. The trend for adoption of these systems is increasing in developing countries (22\% in 2006, 27\% in 2010, and >30\% in 2015) [30,32]. The CBFM system comprises different users of a forest, both living nearby and distant from the forest and with different socioeconomic backgrounds [33]. Their perceptions of the forest-based ES vary significantly according to their livelihood outcomes [34]. The users are the real managers but are victims of ecosystem degradation, and therefore, there is a need to understand their perceptions and take their views into account for effective implementation of forest policy and plans [35]. Knowing the local people's attitudes, considering the needs of the local context of forest-based ES is imperative since this can create three-fold benefits. First, this will create awareness among different sub-groups at the local level of the identification and prioritization of critical forest-based ES. Second, identification and prioritization of forest-based ES will help policy makers and managers assess the needs and aspirations of the different sub-groups involved so that they can formulate practical and applicable forest-based ES management plans. Such an understanding would also help prioritize scarce resources for the successful implementation of forest and natural resource conservation plans. Third, the international community will gain insights into how forest-based ES vary among the sub-groups in the CBFM under consideration and how these ES can be assessed through reaching a consensus in a complex situation.

Nepal is considered a pioneering country in adoption of the CBFM system and its modality has been replicated in many developing countries around the world [30]. There are two major CBFM systems in Nepal, community forestry (CF) and collaborative forest management (CFM). These two CBFM systems manage over 32\% of the total forests in Nepal [36]. The National Forest Strategy Plan 2016-2025 aspires to increase this figure to 39\% (6.6 million ha) by 2025 [36]. Taking a case study of these two CBFM systems, we assess how local users and other stakeholders perceive the importance of forest-based ES based on proximity (nearby vs. distant users), socio-economic class (rich vs. poor users), and forest management modalities (CF vs. CFM).

The significance of this study is further enhanced by the selection of case studies from the Siwalic region, locally known as Chure, which comprises the youngest mountains ranging from 93-1955 metres above mean sea level (masl), and extends over four developing countries: Pakistan, India, Nepal, and Bhutan [37]. In Nepal, it extends over 36 districts and its ES are critically important to large populations in Nepal and in the Bihar and Uttar Pradesh provinces of India. Given its importance to peoples' 
livelihoods and socioeconomic development, the Government of Nepal (GoN) has placed high priority on its conservation and management through its US \$2.49 billion "President Chure-Tarai Madhesh Conservation and Development Programme" $[38,39]$. The programme is gathering information on how different types of forest users and other stakeholders perceive and prioritise forest-based ES in order to prepare a master plan for the region [40].

\section{A Brief Snapshot of Community Forestry (CF) and Collaborative Forestry (CFM) in Nepal}

Although CF and CFM both adopt a CBFM modality, many differences-such as coverage, access to forest ES, use rights, management modalities, exclusion of other users, and alienation of forest areas-exist between them (see Table A1 in Appendix A for details). CF applies to national forests handed over to local forest users for protection, utilization, and management with the objective of fulfilling the forest product and services demands of local communities [41]. About one-third of Nepal's total forest area has been handed over to 22,000 community forest user groups (CFUGs); the National Forest Strategy 2016-2015 aims to add an additional 600,000 hectares by 2025 [36]. CFM, on the other hand, is a partnership model involving the Department of Forests, local governments and local communities for the management of a patch of national forest to fulfil local needs [42]. So far, 28 CFM groups, comprising 3.4 million households, manage nearly 71,000 hectares of forests. By 2025, the Government of Nepal aims for an additional area of 265,000 hectares of forests to be under CFM [36].

CF users can collect and harvest all provisioning ES, whereas CFM users can gain access only for basic forest ES [43]. CF users, through a general assembly, can make all decisions about forest utilization and management, whereas in CFM, mostly the forestry officials and an executive committee make such decisions [43]. In the case of CFM, $50 \%$ of forest product revenue goes to the governments $(40 \%$ to the national government and $10 \%$ to the local government) but in the case of $\mathrm{CF}$, all revenue goes to local users. It is widely claimed that although a large percentage of CFM income goes to government, the contribution from the government is inadequate for managing collaborative forests [44]. Similarly, in the case of CFM, $40 \%$ of the total community income is allocated to forest management, $50 \%$ to poor people and $10 \%$ to community development, whereas in $\mathrm{CF}$, these values are $25 \%, 35 \%$, and $40 \%$, respectively [36]. Although 50\% income allocation to poor people seems high in the case of CFM, it is in fact $20 \%$ of the total income. Furthermore, in the case of CFM, there is no right to alienate forestland to the poor, whereas in CF, some areas of forest can be allocated to poor people for leasing [36]. Therefore, compared to the CFM model, the CF is a more pro-poor forest management model.

\section{Materials and Methods}

\subsection{Study Area}

This study was conducted in Sarlahi District. The district hosts both community and collaborative forests with nearby and distant users. The Sarlahi district is in the central part of Province No. 2, 350 kilometres southeast of Kathmandu, the capital city. The district covers 125,948 hectares, of which $15.5 \%$ are Chure ranges and rest is the Bhawar and the Tarai regions [45]. The elevation of the district ranges from 60 metres above sea level (masl) to 659 masl [46] and consequently it is diverse in climate, vegetation, and land use patterns [37,47].

In the district, the sub-watersheds of the Lakhandehi and Banke rivers were selected for study. The total area of the two watersheds is 15,930 hectares [47]. Cultivated land constitutes almost two-thirds of the area $(66.57 \%)$ followed by forests $(23.31 \%)$ and sand/gravel $(4.31 \%)$ [46,47]. CF and CFM have been implemented in the watershed since the early 2000s with the support of the Biodiversity Sector Programme for Siwalik and Tarai (BISEP-ST), funded by the Government of The Netherlands.

The study investigated two community-based forest management models (one CF and one CFM). These were Shibeshwor CF in the Hariyon municipality, and Phuljor CFM in the Ishworpur municipality, which cover a total area of 3121 hectares of forested area (the CF covering 711 hectares, and CFM 
2419 hectares) (see Figure 1). The Shibeshwor CF comprised 719 households with a population of 4496, while Phuljor CFM consisted of 27,953 households with 161,730 residents [48]. Local users were living both nearby and far from the forests. The nearby users in both the CF and CFM live in the foothills. Agriculture and animal husbandry are the mainstays of their livelihoods. The distant users in the CF live in the semi-urban area and have multiple livelihood options including commercial agriculture, services, and small shops. The distant users in the CFM live some distance away from the forest (>5-20 kilometres) and also depend on agriculture and animal husbandry for their livelihoods [48]. The reasons for selecting these two CBFMs are: (1) both of them have both nearby and distant users; (2) they have a long history of community participation in forest management; (3) the areas are endowed with rich ecosystems [49]. The outcomes of the study are highly applicable to the wider Chure region and to the CBFM model globally.

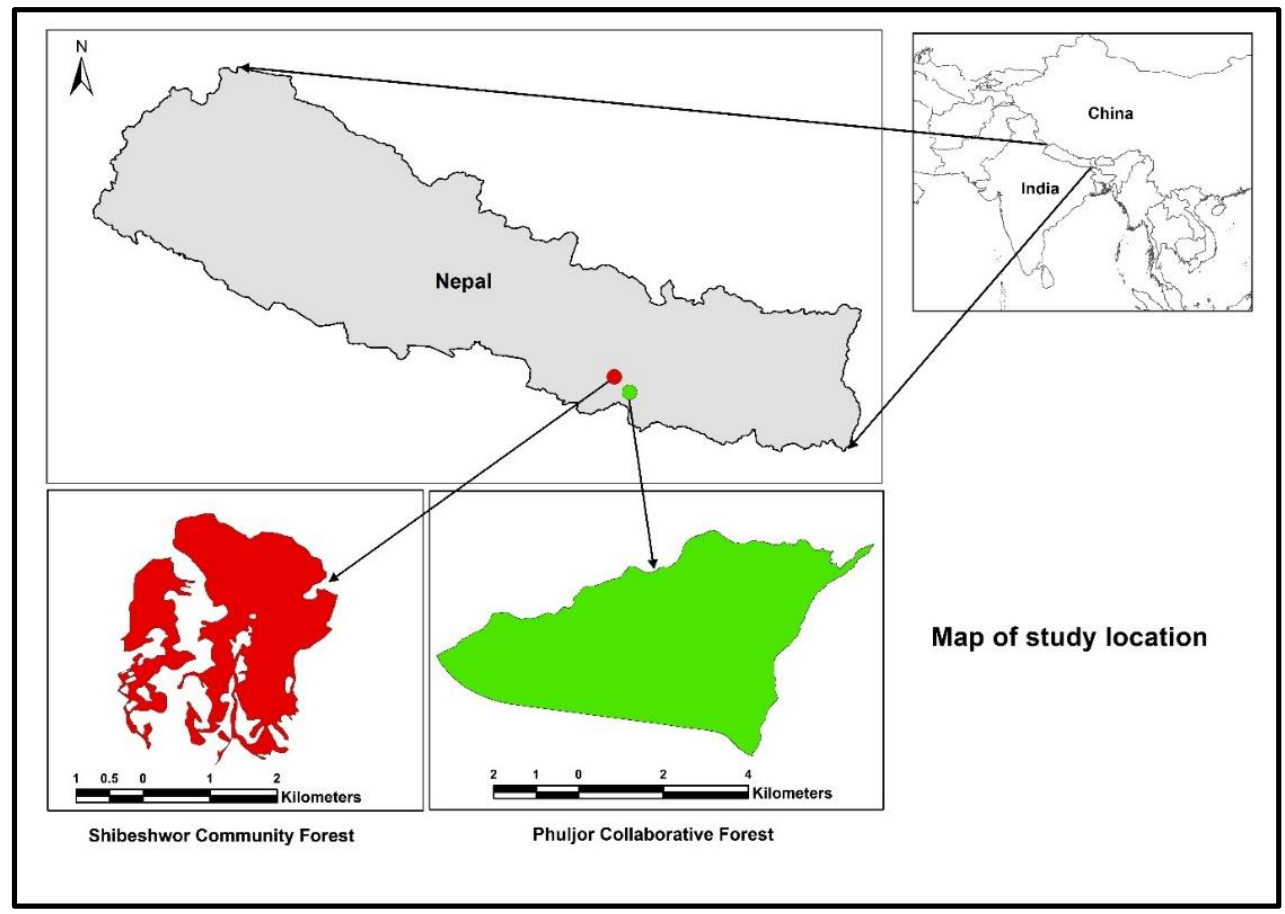

Figure 1. Location map of case study sites (CF and CFM) in Nepal.

\subsection{Assessment and Prioritisation of Ecosystem Services}

\subsubsection{Identification of Ecosystem Services}

A list of potential ES was prepared after reviewing the relevant forests and wetland ecosystem literature, particularly studies conducted in and adjacent to the Chure region [50-53]. We started with Bhandari et al. [50] for a preliminary list—which included 14 provisioning services, 9 regulating services, and 3 cultural services - since their research site is similar to our site and then expanded the list based on other literature. This list was then further augmented through consultation with 29 national experts (an 'expert' is a person with extensive knowledge or ability in ecosystem-based research, experience, or occupation and in particular, having publications in ES and resource management), 17 regional managers ('regional managers' are provincial and district forest officials working in the Chure area directly involved in managing ecosystem services in the Chure region), and eight focus group discussions (FGD). 


\subsubsection{Prioritisation of Ecosystem Services}

The primary data was collected from July to October 2018. The names of potential experts and regional managers were obtained from the President Chure-Tarai Madesh Conservation and Development Board and the District Forest Office Sarlahi. After that, we consulted some of them for suggestions on selecting case study sites to meet our objectives. Subsequently, we carried out multistage sampling, first selecting the district and then the CBFMs and venues for discussions, after ascertaining that the users' participation was high.

Local users' preferences among the range of ESs were identified through FGD which is considered as a suitable tool for assessing people's perceptions of a particular area of interest [54]. As noted, in order to serve our objectives, users were stratified into different strata (rich and poor and nearby and distant users) (Nearby/distant: In collaborative forest management: users living within $5 \mathrm{~km}$ of forests are considered nearby and beyond $5 \mathrm{~km}$ as distant users; in CF living within $3 \mathrm{~km}$ is considered distant. Rich/Poor: CBFM classifies users into four categories (Well-off, Medium, Poor and Very poor). This study includes the first two as Rich and the other two as Poor). The databases for forming these strata were obtained from the constitutions and operational plans of both CBFMs. These databases were further verified through consultations with executive committees. Eight FGDs were conducted, addressing proximity (nearby and distant) and the socio-economic classes (rich and poor). The FGD were conducted in a local language and between 11 and 18 participants took part in the FGD. The main demographic features of the participants are listed in Table 1. A long list of potential ES-developed through the literature review and preliminary consultations with users, experts and forest managers-for each service type was provided to all participants. ES Concept, types (i.e., provisioning, regulating and cultural), importance of various ES to their livelihoods, and the implication of ranking priorities were also discussed. The discussion also addressed the question of how respondents could reach a consensus if there were any misalignments of priorities. Then, adopting the principles set out in Shoyama and Yamagata [55], participants were asked to discuss and unanimously rank all ESs on within services types on the basis of their importance to their livelihoods. The final list of identified forest-based ES suggested 16 provisioning, 15 regulating, and 11 cultural services. Therefore, in case of provisioning services, regulating services, and cultural services, the ranking goes from $1-16$ ( 1 is the least important and 16 is the most important), $1-15$ (1 is the least important and 15 is the most important), and 1-11 (1 is the least important and 11 is the most important), respectively. The respondents agreed that if there is any misalignment among user's priorities, the differences could be settled by a democratic process through a majority vote. They also discussed why they assigned the top score to the particular services in that particular fashion.

\section{Results}

\subsection{Assessment of Ecosystem Services from the Community-Based Forest Management System of Chure Forests}

Local users, regional managers, and experts from the national level identified a total of 42 different ES throughout the region. These were classified based on the Common International Classification of Ecosystem Services (CICES) [56] into three categories: provisioning (16), regulating (15), and cultural (11) services (Figure 2A-C; Appendix B: Table A2). ES are either from extractive uses such as timber, firewood, grasses, sand, boulders, and gravel or non-extractive uses such as regulating climate and water related services as well as being linked to social and cultural values of the local communities such as cultural or religious values or landscape beauty. 
Table 1. Socio-demographic features of the respondents.

\begin{tabular}{|c|c|c|c|c|c|c|c|c|c|c|}
\hline \multirow{2}{*}{$\begin{array}{l}\text { Demographic } \\
\text { Features }\end{array}$} & \multicolumn{2}{|c|}{ CF Nearby } & \multicolumn{2}{|c|}{ CF Distant } & \multicolumn{2}{|c|}{ CFM Nearby } & \multicolumn{2}{|c|}{ CFM Distant } & \multirow{2}{*}{$\begin{array}{c}\text { Regional } \\
\text { Manager }(n=17)\end{array}$} & \multirow{2}{*}{$\begin{array}{l}\text { National Expert } \\
\quad(n=29)\end{array}$} \\
\hline & $\begin{array}{c}\text { Rich } \\
(n=11)\end{array}$ & $\begin{array}{c}\text { Poor } \\
(n=16)\end{array}$ & $\begin{array}{c}\text { Rich } \\
(n=18)\end{array}$ & $\begin{array}{c}\text { Poor } \\
(n=18)\end{array}$ & $\begin{array}{c}\text { Rich } \\
(n=12)\end{array}$ & $\begin{array}{c}\text { Poor } \\
(n=12)\end{array}$ & $\begin{array}{l}\text { Rich } \\
(n=15)\end{array}$ & $\begin{array}{c}\text { Poor } \\
(n=17)\end{array}$ & & \\
\hline Gender & $\begin{array}{c}\mathrm{M}=8 \\
\mathrm{~F}=3\end{array}$ & $\begin{array}{l}\mathrm{M}=6 \\
\mathrm{~F}=10\end{array}$ & $\begin{aligned} \mathrm{M} & =13 \\
\mathrm{~F} & =5\end{aligned}$ & $\begin{array}{l}\mathrm{M}=7 \\
\mathrm{~F}=11\end{array}$ & $\begin{aligned} \mathrm{M} & =8 \\
\mathrm{~F} & =4\end{aligned}$ & $\begin{array}{l}\mathrm{M}=9 \\
\mathrm{~F}=3\end{array}$ & $\begin{aligned} \mathrm{M} & =12 \\
\mathrm{~F} & =3\end{aligned}$ & $\begin{aligned} \mathrm{M} & =12 \\
\mathrm{~F} & =5\end{aligned}$ & $\begin{aligned} \mathrm{M} & =14 \\
\mathrm{~F} & =3\end{aligned}$ & $\begin{aligned} \mathrm{M} & =25 \\
\mathrm{~F} & =4\end{aligned}$ \\
\hline $\begin{array}{c}\text { Median age } \\
\text { (years) }\end{array}$ & 41 (19-75) & $40(18-80)$ & $48(24-79)$ & $\begin{array}{c}48.50 \\
(21-74) \\
\end{array}$ & $39(22-68)$ & $45(20-75)$ & $51(20-84)$ & $45(25-77)$ & $46(31-57)$ & $53.5(29-69)$ \\
\hline Education level & $\begin{array}{l}\mathrm{I}=2 \\
\mathrm{P}=4 \\
\mathrm{~S}=3 \\
\mathrm{~T}=2\end{array}$ & $\begin{array}{c}\mathrm{I}=3 \\
\mathrm{P}=10 \\
\mathrm{~S}=2 \\
\mathrm{~T}=1\end{array}$ & $\begin{array}{l}\mathrm{I}=1 \\
\mathrm{P}=3 \\
\mathrm{~S}=7 \\
\mathrm{~T}=7\end{array}$ & $\begin{array}{l}\mathrm{I}=8 \\
\mathrm{P}=3 \\
\mathrm{~S}=5 \\
\mathrm{~T}=2\end{array}$ & $\begin{array}{l}\mathrm{I}=1 \\
\mathrm{P}=4 \\
\mathrm{~S}=6 \\
\mathrm{~T}=1\end{array}$ & $\begin{array}{l}\mathrm{I}=2 \\
\mathrm{P}=5 \\
\mathrm{~S}=3 \\
\mathrm{~T}=2\end{array}$ & $\begin{array}{l}\mathrm{I}=2 \\
\mathrm{P}=4 \\
\mathrm{~S}=5 \\
\mathrm{~T}=4\end{array}$ & $\begin{array}{l}\mathrm{I}=4 \\
\mathrm{P}=7 \\
\mathrm{~S}=5 \\
\mathrm{~T}=1\end{array}$ & $\mathrm{~T}=17$ & $\mathrm{~T}=29$ \\
\hline $\begin{array}{c}\text { Ethnic } \\
\text { composition }\end{array}$ & $\begin{array}{l}\mathrm{UC}=8 \\
\mathrm{LC}=3\end{array}$ & $\begin{array}{c}\mathrm{UC}=2 \\
\mathrm{LC}=14\end{array}$ & $\begin{aligned} \mathrm{UC} & =16 \\
\mathrm{LC} & =2\end{aligned}$ & $\begin{array}{c}\mathrm{UC}=4 \\
\mathrm{LC}=14\end{array}$ & $\begin{array}{l}\mathrm{UC}=5 \\
\mathrm{LC}=7\end{array}$ & $\begin{array}{l}\mathrm{UC}=3 \\
\mathrm{LC}=9\end{array}$ & $\begin{aligned} \mathrm{UC} & =11 \\
\mathrm{LC} & =4\end{aligned}$ & $\begin{aligned} \mathrm{UC} & =10 \\
\mathrm{LC} & =7\end{aligned}$ & $\begin{array}{l}\mathrm{UC}=10 \\
\mathrm{LC}=7\end{array}$ & $\begin{array}{l}\mathrm{UC}=17 \\
\mathrm{LC}=12\end{array}$ \\
\hline Religion & $\begin{array}{l}\mathrm{H}=9 \\
\mathrm{~B}=2\end{array}$ & $\begin{aligned} \mathrm{H} & =12 \\
\mathrm{~B} & =4\end{aligned}$ & $\mathrm{H}=18$ & $\begin{array}{l}\mathrm{H}=16 \\
\mathrm{M}=2\end{array}$ & $\begin{array}{l}\mathrm{H}=9 \\
\mathrm{~B}=2 \\
\mathrm{M}=1\end{array}$ & $\begin{aligned} \mathrm{H} & =7 \\
\mathrm{~B} & =4 \\
\mathrm{M} & =1\end{aligned}$ & $\mathrm{H}=15$ & $\mathrm{H}=17$ & $\begin{aligned} \mathrm{H} & =14 \\
\mathrm{~B} & =3\end{aligned}$ & $\begin{aligned} \mathrm{H} & =25 \\
\mathrm{~B} & =4\end{aligned}$ \\
\hline
\end{tabular}

Data in parentheses denotes a range; Gender: $\mathrm{M}=$ Male, $\mathrm{F}=$ Female; Education level: $\mathrm{I}$ = Illiterate, $\mathrm{P}=$ Primary/lower secondary, $\mathrm{S}=$ High school educated, $\mathrm{T}=\mathrm{College} \& \mathrm{above}$; Ethnic composition: Higher Caste = Bahun/Kshetri/Dashanami/Madeshi, Lower Caste = Janajati, Janajati/Madhesi, and Dalit; Religion: H = Hindu, B = Buddhist, M = Muslim. 
20

(A) Priority of provisioning services

$\because \mathrm{CFNBR} \square \mathrm{CFNBP} \square \mathrm{CNDR} \square \mathrm{CFDP} \backsim \mathrm{CFNBR} \square \mathrm{CFMNBP} \square \mathrm{CFMDR} \backsim \mathrm{CFMDP} \backsim \mathrm{RM} \backsim \mathrm{NE}$

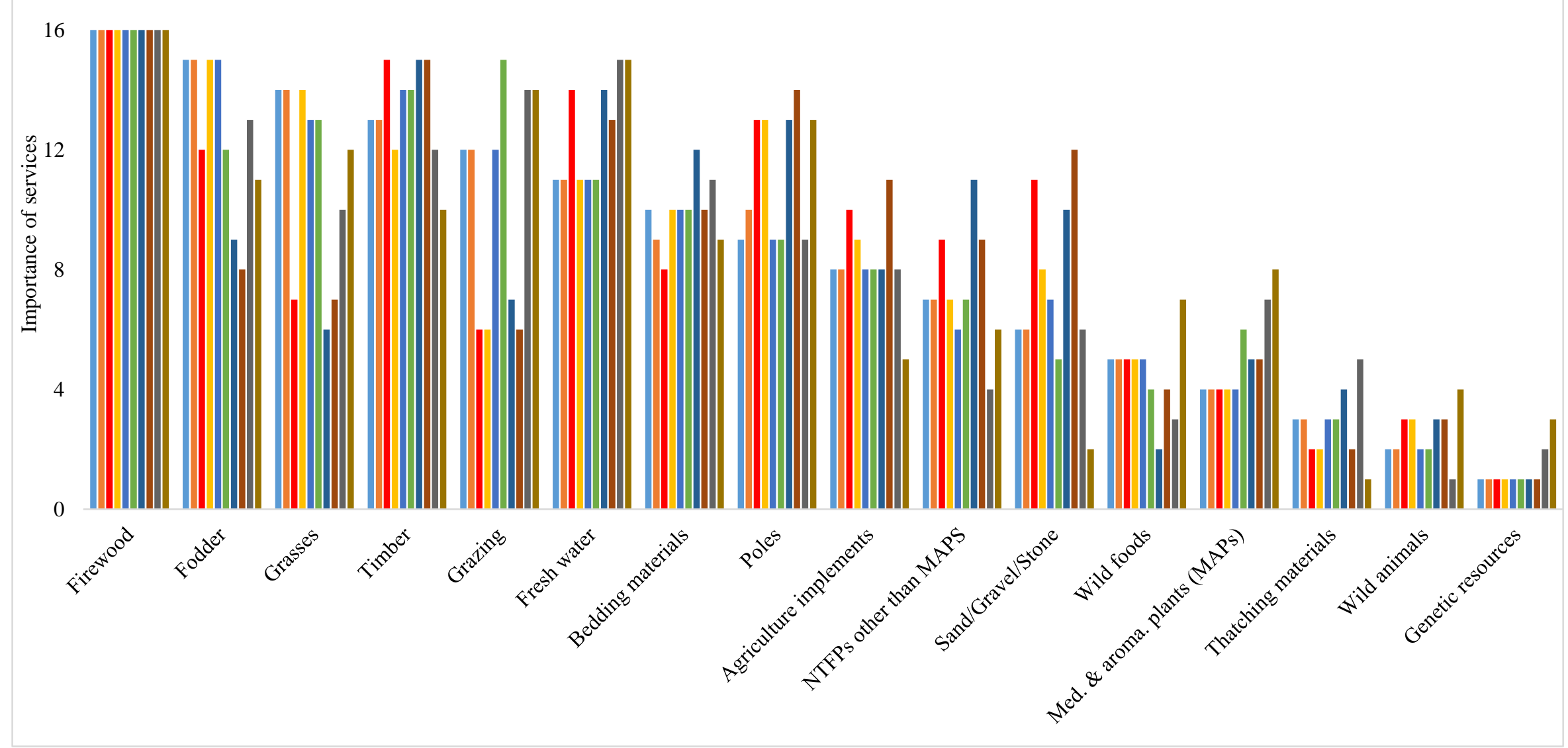

Figure 2. Cont. 


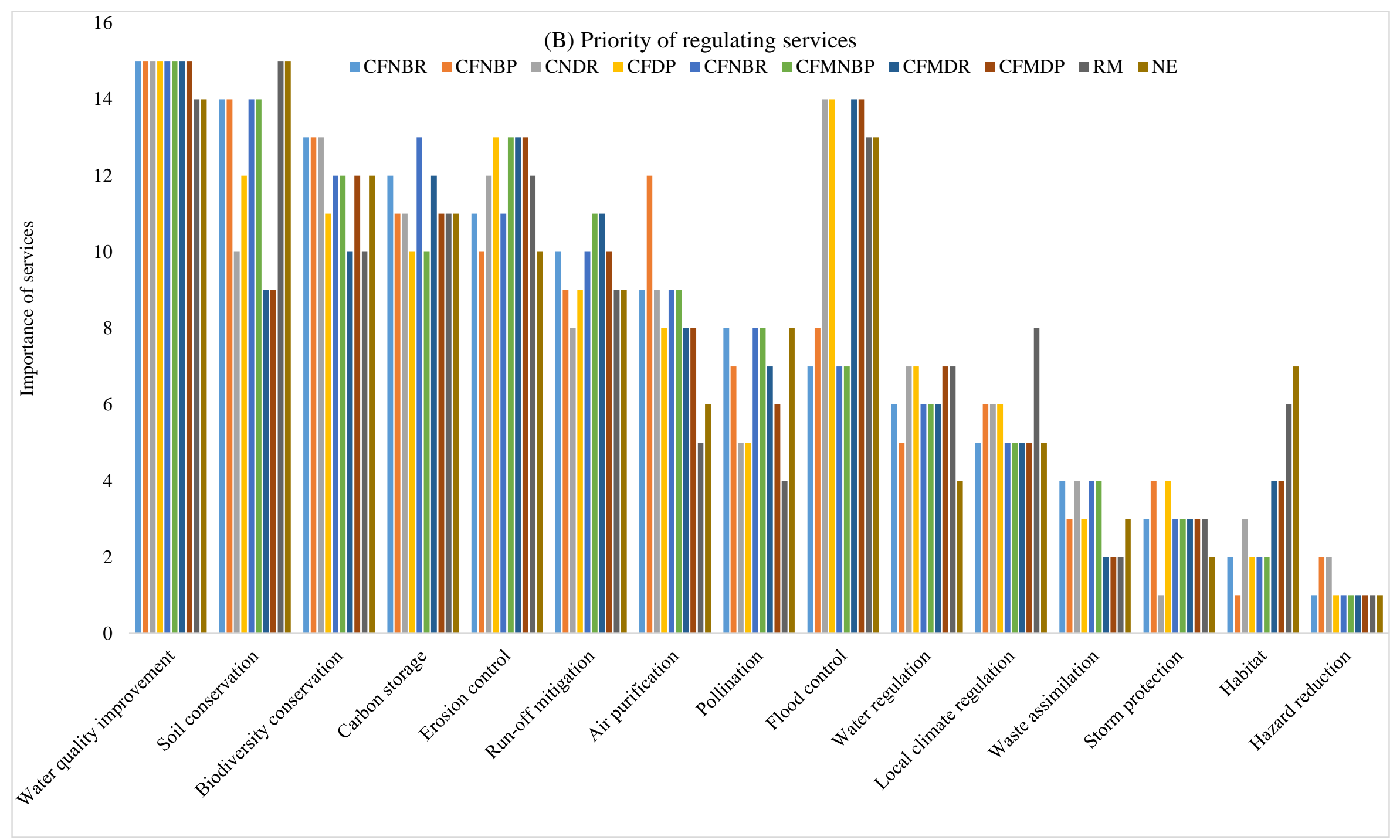

Figure 2. Cont. 


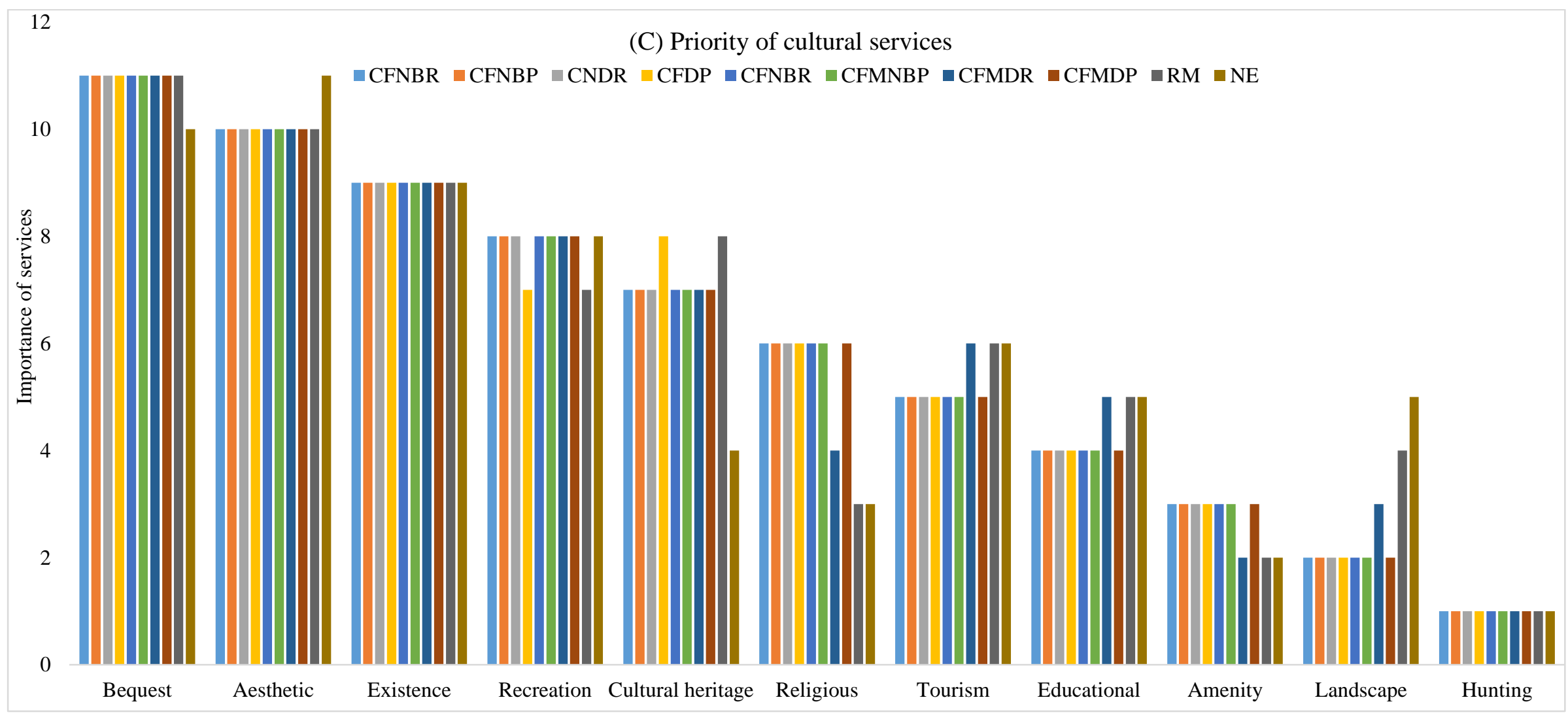

Figure 2. Prioritisation of 16 provisioning (A), 15 regulating (B), and 11 cultural (C) ecosystem services. In the case of provisioning services, regulating services and cultural services, the ranking goes from 1-16 (1 is the least important and 16 is the most important), 1-15 (1 is the least important and 15 is the most important) and 1-11 (1 is the least important and 11 is the most important), respectively. Note: CFNBR $=$ Community Forest Nearby Rich Users, CFNBP = Community Forest Nearby Poor Users, CFDP $=$ Community Forest Distant Rich Users, CFDP $=$ Community Forest Distant Poor Users CFMNBR = Collaborative Forest Management Nearby Rich Users, CFMNBP $=$ Collaborative Forest Management Nearby Poor Users, CFMDR $=$ Collaborative Forest Management Distant Rich Users, CFMDP $=$ Collaborative Forest Management Distant Poor Users, RM = Regional Managers, NE = National Experts. 
In the case of $\mathrm{CF}$, the top priorities of all subgroups were found to be: firewood, fodder, grasses, timber, fresh water, water quality improvement (WQI), soil conservation (SC), biodiversity conservation (BD), flood control (FC), erosion control (EC), bequest, aesthetic, and existence. In the case of CFM, top priorities were firewood, fodder, timber, grazing, fresh water, poles, WQI, SC, BD, FC, EC, bequest, aesthetic, and existence ES.

\subsection{Prioritisation of Various Ecosystem Services from Community-Based Forest Management by Local Users}

Different subgroups had different priorities. Considering all subgroups within the CF, the top three provisioning services were firewood, fodder, timber, grasses, and fresh water. Similarly, the top three regulating and cultural services were WQI, SC, FC, bequest, aesthetic, and existence values.

CFM users, on the other hand, assigned highest priority to firewood, timber, and fresh water as provisioning services, and WQI, carbon, FC, and EC as regulating services. Irrespective of the different management modalities, users placed high priority on bequest, aesthetic, and existence vales as cultural services.

Forest users' priorities on ES differed in relation to their spatial distance from forests. In CF, users living near forests prioritised fodder, grasses, and grazing provisioning services while distant users chose timber, fresh water, and poles. In the case of regulating services, nearby users placed highest priority on SC, and BD services, whereas distant users from the same category placed strong priority on FC and EC services. For cultural services, both nearby and distant users preferred bequest, aesthetic, and existence services and prioritised amenity, landscape, and hunting services least. In the case of CFM, nearby users gave high priority to firewood, fodder and timber while distant users selected firewood, timber, and fresh water provisioning services. Users living adjacent to a forest selected WQI, SC, and carbon sequestration/storage, whereas distant users from the same category nominated WQI, FC, and EC regulating services. Users both nearby and distant from a forest favoured similar cultural services to those selected by the CF users.

Users' priorities differed between higher and lower socioeconomic status groups for many services in the CF. For example, rich users from nearby forests ranked fodder as the second most important service while those of the same status living far from the forest area preferred fresh water. Regarding regulating services, both categories placed WQI in the top rank; however, their priority differed regarding SC. SC was ranked in second position by rich nearby users, whereas the same wealth category living far away ranked this service as sixth priority. In the case of CFM, wealthier users living next to the CFM area preferred fodder, timber, grasses, and grazing services while rich users residing far from forests selected timber, poles, and fresh water services. In terms of regulating services, the priorities of the wealthier users living near the CFM area were similar to those living nearby the $\mathrm{CF}$ area, whereas wealthier users at a greater distance prioritised FC and EC (Figure 2A-C; Appendix B: Table A2).

\subsection{Prioritisation of Various Ecosystem Services by Regional Managers and National Experts in the Chure Region}

The priorities placed on ES by regional managers and national level experts were also mixed. Regional managers assigned fresh water and SC services as their top priorities. The national level experts, on the other hand, placed the highest priority on firewood, SC and aesthetic values. Regional managers and national experts also placed high priority on genetic resources, habitat, landscape beauty, amenity services, and hunting, whereas local forest users prioritised these services least (Figure 2A-C; Appendix B: Table A2). 


\section{Discussion}

\subsection{Identification of Ecosystem Services}

Forest users and other stakeholders identified 42 different ES in the study area which are important to local people's livelihoods and that also contribute to the regional and national economy. These results are comparable with some other studies, both within and outside Nepal. Previous studies have enumerated 19 to 37 different ES from similar localities focusing on forests [35,41,50,53,57-59] and wetlands [51,52].

It has been a challenge to the researchers to explain the high numbers in the results occurring in ES types. For example, a similar study conducted in Panchase area in Nepal acknowledged the landscape mosaic as an important factor [58]. Our study site does not comprise the same mosaic, however it still resulted in a high number of ES identified, probably because of the involvement of a large number of diverse forest stakeholders. Moreover, the Panchase study was based only on CF while our research covers both CF and CFM systems. Furthermore, their case study site was hilly terrain, whereas our study area is a lowland landscape with diverse flora and fauna, and high ethnic and cultural diversity. Our study site has more than 20 different ethnic groups with resulting diversified demands on forest ES [48]. Similarly, about 1308 species of flora and fauna are found in the Chure-Tarai landscape alone $[38,60]$. The higher the number of species and ethnic and cultural groups, the greater the diversity of all ES [61].

Our study revealed a high number of provisioning ES (16) in comparison to regulating (15) and cultural services (11). The findings of our study both coincide with and contradict other studies. For example, Bhandari et al. [50] documented 14 provisioning and 11 regulating services, which is similar to our findings while Adhikari, Baral, and Nitschke [58] identified 19 regulating services in Nepal. Similarly, Chaudhary et al. [41] identified eight provisioning, four regulating, and seven cultural services in Mai Pokhari Ramsar site, Nepal. A study conducted in Sweden in private forests also reported a high number of provisioning services $(n=23)$ [22]. The difference between cases might be due to differences in landscape and ethnicity. The first case study site is similar to our site and revealed similar findings, whereas the second and third study sites have different landscapes and different management modalities. In addition, our study site comprises production forests while the other two sites studied (i.e., Panchase and Mai Pokhari) comprise protection forests with limited use of provisioning services.

\subsection{Differences in Priority of Ecosystem Services among Forests Users, Regional Managers, and National Experts}

\subsubsection{Differences among Different Sub-Groups of Community Forests and Collaborative Forest Management}

The findings revealed that, irrespective of management modalities, all users ranked firewood, water quality improvement (WQI), and bequest values as top priority. Some of the possible reasons behind these preferences could be similarity in the use pattern, an increased need for these services as well as the socio-cultural beliefs of those sub-groups. More than $80 \%$ of the households in the Chure region use firewood for cooking [38] and the total demand for firewood in both CBFMs is 403,112 (35,512 bhari required by CF and 367,600 bhari by CFM) bhari (Bhari is a local unit of measurement. One bhari is a head load carried by an individual, approximately equivalent to $25 \mathrm{~kg}$ ) [48]. Rich-distant users employ an energy mix such as liquefied petroleum gas (LPG) and bio-gas, however, most of the population regardless of their economic status rear cattle and firewood is necessary for cooking cattle feed, locally called Khole. In addition, all sub-groups use firewood for heating in winter. According to FAO about 2.4 billion people make use of fuelwood for cooking, boiling water, and heating globally [8]. In the case of developing countries, fuelwood is the prime source of energy. Our case study sites concur with the findings of others studies $[8,35,62]$. Likewise, both water quality and quantity are of serious ongoing concern for inhabitants of Chure and Tarai, mainly due to the influx of hill migrants 
and increased water use coupled with the fragile topography and the low water holding capacity of the landscape $[37,38,63]$. Similar results have been recorded in other parts of the world e.g., in the dry northern region of Kenya [61] and the Chittagong Hill Tracts in Bangladesh [62]. Similarly, bequest value is categorised as a non-use value, which is a special case of option value that represents the value (to current users) of being able to bequeath the forest to future generations $[64,65]$. As the local users of the study area strongly believe in reincarnation and saving for future generations, forest users may have prioritised bequest services for their children and grandchildren [66]. Therefore, all sub-groups ranked these services amongst their top priorities.

Regardless of their economic status and management modalities, all users from both CBFMs regarded many critical services, for example genetic resources, hazard protection, and hunting services as least priority. The reason for this might be associated with the level of awareness of the importance of many ES. Although the landscape approach in the Tarai-Arc Landscape (TAL) programme was implemented in the Chure and Tarai regions in 2004, their focus has only been on 13 western districts [63]. The TAL excludes the eastern Tarai region, where our study area is located. Furthermore, both CBFM have completely prohibited the hunting of any wild animals [48,67]. This could be why hunting services were given lowest priority.

The findings indicated a clear difference in the priority rankings among nearby and distant users in CFM; such difference might be influenced by number of factors, primarily the benefits accruing from the forests [26,41]. In general, local users from the CFM placed highest priority on the ES based on the benefits that they would have to their individual livelihoods. For example, the nearby users of both socioeconomic groups prioritised grasses 4th while distant users in same category placed grasses 8th and 10th. This is comparable with communities' priorities in other empirical studies [35,68,69]. Nearby forest users, show a greater preference for direct use services as they receive higher benefits from these as compared to more distant users. Hence, the level of tangible benefits received by the users could be one of the primary determinants of prioritising the ES.

In our study, proximity to a forest area also influenced the prioritisation of the ES. Users living nearby forests under CF preferred daily use services such as fodder, grasses, and grazing, whereas users living farther from the forest area prioritised timber and fresh water. The possible reasons for variation in priority among these sub-groups might be differences in location, occupation, demand, price, and use pattern of the services. For instance, as previously mentioned when discussing our methodology, the nearby users in CF live in the hills and rely solely on agriculture and animal husbandry for their livelihoods. About three quarters of these households raise cattle ranging in number from one to seven head and total demand for fodder and grasses is almost 21,256 bhari [67]. The more distant users of a $\mathrm{CF}$, on the other hand, live in semi-urban areas and have multiple livelihood options including cash crop cultivation, government and other jobs, and small businesses. They prioritised timber and poles, since the market price of timber in the semi-urban area is high. Comparable findings were reported in Java, Indonesia, where location of residents and livestock holdings determined the selection of forest-based ES [35]. Purchasing timber and poles from the market is almost 10 times more expensive than obtaining these services from the CF. In addition, fresh water is of special interest for distant rich users since large farmers cultivate sugarcane [70] and irrigate their sugarcane farms. These might be key reasons behind the differences in priority placed on provisioning services among CF users.

In the case of CFM, the nearby users favoured fodder, timber, and grasses while distant users selected timber, poles and fresh water services. Access to benefit sharing, distance to the forest area, and demand for scarce services could be potential reasons for selecting these services. As noted, CFM is a partnership model among national and local governments and local communities for the management of a block of national forest to fulfil the needs of local people [42]. In CFM, the level of access to benefit sharing by users distant to a forest area is different to that of CF [43]. In the case of CFM, $50 \%$ of forest product revenue goes to the governments ( $40 \%$ to national government and $10 \%$ to the local government) but there is no such provision in CF [43,44]. CF users reside near forests (nearby users live adjacent to the forest area and distant users live almost two to three $\mathrm{km}$ from a forest) 
while under CFM, distant users reside over five $\mathrm{km}$ away [33]. As the nearby users raise livestock (average of four to eight head of cattle per livestock-keeping household (HHs)) and require substantial amounts of forage, their priority is fodder and grasses. Likewise, as many users in the CFM system live 5-20 kilometres away from the forest area [48], they cannot collect daily use services such as fodder and grasses [33]. A study conducted in Tanzania reported contrasting findings [71], suggesting that most of provisional ES were utilized within one $\mathrm{km}$ radius of the forest, but in our case, many ES such as timber, poles and firewood are used up to $20 \mathrm{~km}$ away from the forests. Users do, however, consider forests as the source of timber, poles, and the fresh water and therefore prioritise these services accordingly.

Likewise, socio-economic and topographic factors play important roles in prioritising regulating services. The wealthier users adjacent to both CBFMs assigned top priority to SC, BD, and carbon sequestration services while users within the same wealth group living far from forests assigned high priority to FC and EC services. The Chure region is highly susceptible to soil erosion [39,72] and the Dun and Tarai-Madesh regions are susceptible to flooding [38,40]. Users living nearby the Chure forests face acute soil loss problems in the region [38-40]. On average, 16 to 64 tonnes of soil are lost every year [72,73]. The Tarai/distant region, on the other hand, faces frequent flooding: in 2017 flooding caused severe losses in 18 Tarai districts worth US $\$ 584.7$ million [74]. Due to experiencing recent flood damage, distant users might have been influenced to select FC services as the top priority.

As presented in the study results, all sub-groups in both management modalities recognised the benefits of carbon storage and sequestration services (CSS) and ranked these fourth to sixth. Surprisingly, they currently receive no benefit from CSS though still choose this as a high priority. However, they have heard about the Reducing Emissions from Deforestation and Forests Degradation (REDD+) pilot projects implemented in nearby districts (Chitwan, Dolakha, and Gorkha districts). These projects have provided many financial benefits to the local users in accordance with their contribution to social and environmental safeguards [31,75]. Similarly, the Nepalese government, along with World Wildlife Fund for Nature (WWF) recently initiated REDD+ projects in 12 TAL districts, adjacent to our study site [36,76]. With a total budget of US\$177.1 million, 14 metric tonnes of carbon dioxide equivalent $\left(\mathrm{MtCO}_{2}\right.$ e) (A metric measure used to compare the emissions from different greenhouse gases based upon their global warming potential. The carbon dioxide equivalent for a gas is derived by multiplying tons of the gas by its associated global warming potential) will have been credited to the World Bank Carbon Fund [36]. Although users in our research site have not received any carbon benefits so far, these initiatives in nearby districts may have created some awareness about them and users might have been more optimistic at the time of the study about the carbon benefits coming in the near future.

\subsubsection{Differences between Regional Managers and National Experts}

Regional and nation stakeholders share many similarities, although they have slightly different priorities for bequest services. Regional managers regard bequest value as the top priority, whereas the national stakeholders ranked this in second position. Regional managers stayed longer in the region and have a more in-depth understanding of the current field situation than national stakeholders. Studies conducted in Israel and Slovenia concur with this finding [77,78]. Practical and field experience can enhance identification and better prioritization of the ES. Consistent with this, regional managers tend to see with the eyes of local users whereas the national experts' input reflects national perspectives. The national experts, however, have more international exposure and have more knowledge of the global literature, which might have influenced their perceptions.

\subsection{Policy Implications of the Study}

This study identified and prioritized a wide range of forest-based provisioning, regulating, and cultural ecosystem services. Many of these services are not documented in the operational/management plans of both forests management systems [79]. Considering the increasing tendency toward valuing such services, it is essential to document them in management plans for CBFM projects. Furthermore, 
our study revealed the differences in priorities between sub-groups in both CF and CFM, however, up until now the plans of CBFM have not internalized these issues. In the CF, for instance, users living nearby prioritised fodder and grass services as highest priority but the current management plans do not incorporate ways of optimizing the values of these services. In the case of CFM, the operational plan largely focuses on timber production, while high priority is placed on firewood by distant users. Moreover, poor users living nearby also need a substantial amount of fodder, grasses, and grazing services but the management plan does not consider these pertinent issues. Users acknowledged that it is not possible to include all prioritized ecosystem services from all sub-groups in the management plans but it is crucial to consider at least the top five priorities from each sub-group. This provision would make all users feel that their interests and priorities are included. As a result, they will be motivated for to act for conservation and sustainable management of their forests. At the same time, mismatches of different groups should be equally considered for managing potential areas of conflict in the long run.

How we can include the provision of forest-based ecosystem services in an operational plan could raise some issues. As noted, in the CBFM system, part of the national forest is legally handed over to the local community for protection, management and utilization [80]. The process is supported by government policies, rules, and regulations. In the case of Nepal, Forest Act 1991, Forest Regulations 1995, and National Forest Strategy Plan 2016-2025 provide a roadmap and clearly specify the possible roles, responsibilities and inputs of communities, government, and non-government facilitators [36,81]. Once the user group's constitution and working plan are negotiated and signed by the users and government department-in the case of Nepal, the Divisional Forest Officer (DFO) - a given patch of national forest legally becomes a community forest. The operational plan of a CBFM system must be renewed at regular intervals for its perpetuity. The process and provision of securing prioritized forest-based ES could be incorporated into the revised operational plan for full-fledged implementation.

\section{Conclusions}

This study assesses and prioritizes key forest-based ecosystem services in community and collaborative forests in the Chure region of Nepal. The findings show that the Chure landscape provides approximately 42 ecosystem services for local, regional, national, and international users. This high number of ecosystem services is attributed to the high diversity of flora and fauna, and to the cultural and ethnic diversity in the study areas. Results also show both similarities and differences in the prioritization of the ecosystem services among different user groups, largely influenced by their forest management modalities (community forests and collaborative forests), proximity to forest area (nearby and distant) and socio-economic status (rich and poor). The similarities can determine common areas of interest among larger stakeholders, while the differences can indicate potential areas of conflict when implementing the management plans.

The mismatches in prioritization of ecosystem services among the subgroups of users generates complexities for forest management. Although obtaining consensus among different subgroups is not possible in such a large and socio-economically and culturally diverse landscape, it is imperative for better management of forest resources. Considering the priorities of regional managers and national experts is equally important, despite adding further complexity. Therefore, promoting the culture of multi-stakeholder consultation process towards achieving consensus among them is necessary. Once the interests of all stakeholders are negotiated and agreed upon, the process and provision of securing those ecosystem services should be included in the forest operational plans during their revision. 
The outcomes of this research could be useful for a number of purposes: (1) two ongoing large programmes in Nepal- "President Chure-Tarai-Madhesh Conservation and Development Programme" and "Tarai Arc Landscape Programme"-could consider the users' priorities for channeling and prioritizing their scarce resources; (2) the priority of ecosystem services for different users may change over time. This study provides benchmark data for change assessment; and (3) the research-sampling framework developed in this study can be applied in any community-based forest management (CBFM) system in developing countries.

Due to the scarcity of resources, this study was not able to cover all forest user groups. Therefore, more research across a larger number of community and collaborative forests is required to determine whether these results are indicative of the entire Chure region.

Author Contributions: R.P.A., conceptualisation and writing; T.N.M., overall guidance and framing the concept; G.C., overall guidance and framing the concept.

Acknowledgments: The authors would like to thank Endeavour Postgraduate Scholarship Programme, Australia and the University of Southern Queensland, Australia, for supporting the research work. Special thanks to community members and the field team (Prashant Paudyal, Simant Rimal, Avash Pradhan, and Subash Kushwah). The paper also benefitted from feedback received from many scholars. We highly appreciate the editorial support from Susanne Holzknecht and constructive feedback from editors and reviewers, which helped to clarify our ideas and improve the manuscript.

Conflicts of Interest: The authors declare that there is no conflict of interest.

\section{Appendix A}

Table A1. Difference between Community Forests and Collaborative Forest Management in Nepal.

\begin{tabular}{|c|c|c|}
\hline Features & Community Forests & Collaborative Forests \\
\hline Concept & $\begin{array}{l}\text { CF are national forests handed over to } \\
\text { forest users for protection, utilisation and } \\
\text { management of forests with the objective } \\
\text { of fulfilling forest product and services } \\
\text { demands of the local communities }\end{array}$ & $\begin{array}{l}\text { CFM is a partnership model between } \\
\text { Department of Forests (DoF), local government } \\
\text { and local communities for the management of a } \\
\text { patch of national forest to fulfil the local needs } \\
\text { (both nearby and distant users) of many } \\
\text { ecosystem goods and services such as timber, } \\
\text { firewood and other non-timber forest products }\end{array}$ \\
\hline History & Initiated in late $1980 \mathrm{~s}$ & Initiated after $2000 \mathrm{~s}$ \\
\hline Coverage & $\begin{array}{c}1.81 \text { million hectares of forests among } \\
\text { 19,361 CFUG groups across Nepal Tarai, } \\
\text { Chure, Midhills, and High Mountain } \\
\text { regions }\end{array}$ & $\begin{array}{c}0.071 \text { million hectares of forests area managed } \\
\text { by } 28 \text { CFM groups ( } 3.4 \text { million HHs) in Tarai } \\
\text { and Chure regions }\end{array}$ \\
\hline Access & $\begin{array}{c}\text { Each member has access rights as per the } \\
\text { prescribed management plan }\end{array}$ & $\begin{array}{l}\text { Forest users have rights to enter the forest } \\
\text { within specified times and months }\end{array}$ \\
\hline Use/management right & $\begin{array}{c}\text { Users can decide and extract, collect and } \\
\text { harvest all provisioning ES }\end{array}$ & $\begin{array}{l}\text { Users can get regular access only for basic forest } \\
\text { services such as fodder, grasses, and other } \\
\text { non-timber forests products }\end{array}$ \\
\hline Exclusion of non-users & $\begin{array}{l}\text { Users have rights to include and exclude } \\
\text { users, and utilisation of forests services }\end{array}$ & $\begin{array}{l}\text { Forestry officials and executive committee } \\
\text { mostly decide about the users, utilisation and } \\
\text { management of forest services }\end{array}$ \\
\hline Sharing of Revenue & $\begin{array}{l}100 \% \text { of income goes to local users but } \\
15 \% \text { of revenue from commercial } \\
\text { transactions of Acacia catechu and Shorea } \\
\text { robusta goes to central government. }\end{array}$ & $\begin{array}{l}50 \% \text { of all timber income goes to central and } \\
\text { local governments and another } 50 \% \text { to the local } \\
\text { government. }\end{array}$ \\
\hline Provision on forest management & $\begin{array}{l}\text { Allocation of } 25 \% \text { of total income of CF } \\
\text { for forest management }\end{array}$ & $\begin{array}{l}\text { Allocation of } 40 \% \text { of total income of CFM for } \\
\text { forest management }\end{array}$ \\
\hline Alienation of land forest land & $\begin{array}{c}\text { CF can decide to allocate a piece of land to } \\
\text { poor groups }\end{array}$ & There is no such provision in CFM \\
\hline
\end{tabular}




\section{Appendix B}

Table A2. Relative importance of different forest-based ecosystem services to sub-groups and other stakeholders.

\begin{tabular}{|c|c|c|c|c|c|c|c|c|c|c|c|}
\hline \multirow{2}{*}{ Service Types } & \multirow{2}{*}{ Category } & \multicolumn{2}{|c|}{ CF Nearby } & \multicolumn{2}{|c|}{ CF Distant } & \multicolumn{2}{|c|}{ CFM Nearby } & \multicolumn{2}{|c|}{ CFM Distant } & \multirow{2}{*}{$\begin{array}{c}\text { Regional } \\
\text { Managers }\end{array}$} & \multirow{2}{*}{$\begin{array}{c}\text { National } \\
\text { Experts }\end{array}$} \\
\hline & & Rich & Poor & Rich & Poor & Rich & Poor & Rich & Poor & & \\
\hline \multirow{16}{*}{$\begin{array}{l}\text { Provisioning } \\
\text { Services }\end{array}$} & Firewood & 16 & 16 & 16 & 16 & 16 & 16 & 16 & 16 & 16 & 16 \\
\hline & Fodder & 15 & 15 & 12 & 15 & 15 & 12 & 9 & 8 & 13 & 11 \\
\hline & Grasses & 14 & 14 & 7 & 14 & 13 & 13 & 6 & 7 & 10 & 12 \\
\hline & Timber & 13 & 13 & 15 & 12 & 14 & 14 & 15 & 15 & 12 & 10 \\
\hline & Grazing & 12 & 12 & 6 & 6 & 12 & 15 & 7 & 6 & 14 & 14 \\
\hline & Fresh water & 11 & 11 & 14 & 11 & 11 & 11 & 14 & 13 & 15 & 15 \\
\hline & Bedding materials & 10 & 9 & 8 & 10 & 10 & 10 & 12 & 10 & 11 & 9 \\
\hline & Poles & 9 & 10 & 13 & 13 & 9 & 9 & 13 & 14 & 9 & 13 \\
\hline & $\begin{array}{l}\text { Agriculture } \\
\text { implements }\end{array}$ & 8 & 8 & 10 & 9 & 8 & 8 & 8 & 11 & 8 & 5 \\
\hline & $\begin{array}{c}\text { NTFPs other than } \\
\text { MAPS }\end{array}$ & 7 & 7 & 9 & 7 & 6 & 7 & 11 & 9 & 4 & 6 \\
\hline & Sand/Gravel/Stone & 6 & 6 & 11 & 8 & 7 & 5 & 10 & 12 & 6 & 2 \\
\hline & Wild foods & 5 & 5 & 5 & 5 & 5 & 4 & 2 & 4 & 3 & 7 \\
\hline & $\begin{array}{l}\text { Med. \& aroma. plants } \\
\text { (MAPs) }\end{array}$ & 4 & 4 & 4 & 4 & 4 & 6 & 5 & 5 & 7 & 8 \\
\hline & Thatching materials & 3 & 3 & 2 & 2 & 3 & 3 & 4 & 2 & 5 & 1 \\
\hline & Wild animals & 2 & 2 & 3 & 3 & 2 & 2 & 3 & 3 & 1 & 4 \\
\hline & Genetic resources & 1 & 1 & 1 & 1 & 1 & 1 & 1 & 1 & 2 & 3 \\
\hline \multirow{15}{*}{$\begin{array}{l}\text { Regulating } \\
\text { Services }\end{array}$} & $\begin{array}{l}\text { Water quality } \\
\text { improvement }\end{array}$ & 15 & 15 & 15 & 15 & 15 & 15 & 15 & 15 & 14 & 14 \\
\hline & Soil conservation & 14 & 14 & 10 & 12 & 14 & 14 & 9 & 9 & 15 & 15 \\
\hline & $\begin{array}{l}\text { Biodiversity } \\
\text { conservation }\end{array}$ & 13 & 13 & 13 & 11 & 12 & 12 & 10 & 12 & 10 & 12 \\
\hline & Carbon storage & 12 & 11 & 11 & 10 & 13 & 10 & 12 & 11 & 11 & 11 \\
\hline & Erosion control & 11 & 10 & 12 & 13 & 11 & 13 & 13 & 13 & 12 & 10 \\
\hline & Run-off mitigation & 10 & 9 & 8 & 9 & 10 & 11 & 11 & 10 & 9 & 9 \\
\hline & Air purification & 9 & 12 & 9 & 8 & 9 & 9 & 8 & 8 & 5 & 6 \\
\hline & Pollination & 8 & 7 & 5 & 5 & 8 & 8 & 7 & 6 & 4 & 8 \\
\hline & Flood control & 7 & 8 & 14 & 14 & 7 & 7 & 14 & 14 & 13 & 13 \\
\hline & Water regulation & 6 & 5 & 7 & 7 & 6 & 6 & 6 & 7 & 7 & 4 \\
\hline & $\begin{array}{l}\text { Local climate } \\
\text { regulation }\end{array}$ & 5 & 6 & 6 & 6 & 5 & 5 & 5 & 5 & 8 & 5 \\
\hline & Waste assimilation & 4 & 3 & 4 & 3 & 4 & 4 & 2 & 2 & 2 & 3 \\
\hline & Storm protection & 3 & 4 & 1 & 4 & 3 & 3 & 3 & 3 & 3 & 2 \\
\hline & Habitat & 2 & 1 & 3 & 2 & 2 & 2 & 4 & 4 & 6 & 7 \\
\hline & Hazard reduction & 1 & 2 & 2 & 1 & 1 & 1 & 1 & 1 & 1 & 1 \\
\hline \multirow{11}{*}{$\begin{array}{l}\text { Cultural } \\
\text { Services }\end{array}$} & Bequest & 11 & 11 & 11 & 11 & 11 & 11 & 11 & 11 & 11 & 10 \\
\hline & Aesthetic & 10 & 10 & 10 & 10 & 10 & 10 & 10 & 10 & 10 & 11 \\
\hline & Existence & 9 & 9 & 9 & 9 & 9 & 9 & 9 & 9 & 9 & 9 \\
\hline & Recreation & 8 & 8 & 8 & 7 & 8 & 8 & 8 & 8 & 7 & 8 \\
\hline & Cultural heritage & 7 & 7 & 7 & 8 & 7 & 7 & 7 & 7 & 8 & 4 \\
\hline & Religious & 6 & 6 & 6 & 6 & 6 & 6 & 4 & 6 & 3 & 3 \\
\hline & Tourism & 5 & 5 & 5 & 5 & 5 & 5 & 6 & 5 & 6 & 6 \\
\hline & Educational & 4 & 4 & 4 & 4 & 4 & 4 & 5 & 4 & 5 & 5 \\
\hline & Amenity & 3 & 3 & 3 & 3 & 3 & 3 & 2 & 3 & 2 & 2 \\
\hline & Landscape & 2 & 2 & 2 & 2 & 2 & 2 & 3 & 2 & 4 & 5 \\
\hline & Hunting & 1 & 1 & 1 & 1 & 1 & 1 & 1 & 1 & 1 & 1 \\
\hline
\end{tabular}

\section{References}

1. Gómez-Baggethun, E.; De Groot, R.; Lomas, P.L.; Montes, C. The history of ecosystem services in economic theory and practice: From early notions to markets and payment schemes. Ecol. Econ. 2010, 69, 1209-1218.

[CrossRef] 
2. Costanza, R.; d'Arge, R.; De Groot, R.; Farber, S.; Grasso, M.; Hannon, B.; Limburg, K.; Naeem, S.; O’Neill, R.V.; Paruelo, J.; et al. The value of the world's ecosystem services and natural capital. Nature 1997, 387, 253-260. [CrossRef]

3. Costanza, R.; De Groot, R.; Sutton, P.; Van der Ploeg, S.; Anderson, S.J.; Kubiszewski, I.; Farber, S.; Turner, R.K. Changes in the global value of ecosystem services. Glob. Environ. Chang. 2014, 26, 152-158. [CrossRef]

4. MEA. Ecosystems and Human Well-Being: Synthesis; Island Press: Washington, DC, USA, 2005.

5. TEEB. The Economics of Ecosystem and Biodiversity, Mainstreaming the Economics of Nature: A Synthesis of the Approach, Conclusions and Recommendations of TEEB; TEEB: Geneva, Switzerland, 2010.

6. Pasgaard, M.; Van Hecken, G.; Ehammer, A.; Strange, N. Unfolding scientific expertise and security in the changing governance of ecosystem services. Geoforum 2016, 84, 354-367. [CrossRef]

7. Food and Agriculture Organisation of the United Nations. Forest Resources Assessment 2015: How Are the World's Forests Changing? Food and Agriculture Organisation of the United Nations, FAO Publishing: Rome, Italy, 2015.

8. Food and Agriculture Organisation of the United Nations. The State of the World's Forests 2018-Forest Pathways to Sustainable Development; Food and Agriculture Organisation, FAO Publishing: Rome, Italy, 2018.

9. McDonough, K.; Hutchinson, S.; Moore, T.; Hutchinson, J.M.S. Analysis of publication trends in ecosystem services research. Ecosyst. Serv. 2017, 25, 82-88. [CrossRef]

10. Reed, J.; Van Vianen, J.; Foli, S.; Clendenning, J.; Yang, K.; MacDonald, M.; Petrokofsky, G.; Padoch, C.; Sunderland, T. Trees for life: The ecosystem service contribution of trees to food production and livelihoods in the tropics. For. Policy Econ. 2017, 84, 62-71. [CrossRef]

11. Ninan, K.N.; Kontoleon, A. Valuing forest ecosystem services and disservices-Case study of a protected area in India. Ecosyst. Serv. 2016, 20, 1-14. [CrossRef]

12. Birch, J.C.; Thapa, I.; Balmford, A.; Bradbury, R.B.; Brown, C.; Butchart, S.H.M.; Gurung, H.; Hughes, F.M.R.; Mulligan, M.; Pandeya, B.; et al. What benefits do community forests provide, and to whom? A rapid assessment of ecosystem services from a Himalayan forest, Nepal. Ecosyst. Serv. 2014, 8, 118-127.

13. Pandeya, B.; Buytaert, W.; Zulkafli, Z.; Karpouzoglou, T.; Mao, F.; Hannah, D.M. A comparative analysis of ecosystem services valuation approaches for application at the local scale and in data scarce regions. Ecosyst. Serv. Part B 2016, 22, 250-259. [CrossRef]

14. Akujärvi, A.; Lehtonen, A.; Liski, J. Ecosystem services of boreal forests-Carbon budget mapping at high resolution. J. Environ. Manag. 2016, 181, 498-514. [CrossRef]

15. Forsius, M.; Akujärvi, A.; Mattsson, T.; Holmberg, M.; Punttila, P.; Posch, M.; Liski, J.; Repo, A.; Virkkala, R.; Vihervaara, P. Modelling impacts of forest bioenergy use on ecosystem sustainability: Lammi LTER region, southern Finland. Ecol. Indic. 2016, 65, 66-75. [CrossRef]

16. Langner, A.; Irauschek, F.; Perez, S.; Pardos, M.; Zlatanov, T.; Öhman, K.; Nordström, E.M.; Lexer, M.J. Value-based ecosystem service trade-offs in multi-objective management in European mountain forests. Ecosyst. Serv. 2017, 26, 245-257. [CrossRef]

17. Verkerk, P.J.; Mavsar, R.; Giergiczny, M.; Lindner, M.; Edwards, D.; Schelhaas, M.J. Assessing impacts of intensified biomass production and biodiversity protection on ecosystem services provided by European forests. Ecosyst. Serv. 2014, 9, 155-165. [CrossRef]

18. Verma, M.; Negandhi, D.; Khanna, C.; Edgaonkar, A.; David, A.; Kadekodi, G.; Costanza, R.; Gopal, R.; Bonal, B.S.; Yadav, S.P.; et al. Making the hidden visible: Economic valuation of tiger reserves in India. Ecosyst. Serv. 2017, 26, 236-244. [CrossRef]

19. Parthum, B.; Pindilli, E.; Hogan, D. Benefits of the fire mitigation ecosystem service in The Great Dismal Swamp National Wildlife Refuge, Virginia, USA. J. Environ. Manag. 2017, 203, 375-382. [CrossRef] [PubMed]

20. Turpie, J.K.; Forsythe, K.J.; Knowles, A.; Blignaut, J.; Letley, G. Mapping and valuation of South Africa's ecosystem services: A local perspective. Ecosyst. Serv. 2017, 27, 179-192. [CrossRef]

21. Kubiszewski, I.; Costanza, R.; Dorji, L.; Thoennes, P.; Tshering, K. An initial estimate of the value of ecosystem services in Bhutan. Ecosyst. Serv. 2013, 3, e11-e21. [CrossRef]

22. Garrido, P.; Elbakidze, M.; Angelstam, P. Stakeholders' perceptions on ecosystem services in Östergötland's (Sweden) threatened oak wood-pasture landscapes. Landsc. Urban Plan. 2017, 158, 96-104. [CrossRef]

23. Fagerholm, N.; Torralba, M.; Burgess, P.J.; Plieninger, T. A systematic map of ecosystem services assessments around European agroforestry. Ecol. Indic. 2016, 62, 47-65. [CrossRef] 
24. Nieto-Romero, M.; Oteros-Rozas, E.; González, J.A.; Martín-López, B. Exploring the knowledge landscape of ecosystem services assessments in mediterranean agroecosystems: Insights for future research. Environ. Sci. Policy 2014, 37, 121-133. [CrossRef]

25. Vihervaara, P.; Rönkä, M.; Walls, M. Trends in ecosystem service research: Early steps and current drivers. AMBIO 2010, 39, 314-324. [CrossRef] [PubMed]

26. Daw, T.; Brown, K.; Rosendo, S.; Pomeroy, R. Applying the ecosystem services concept to poverty alleviation: The need to disaggregate human well-being. Environ. Conserv. 2011, 38, 370-379. [CrossRef]

27. Christie, M.; Rayment, M. An economic assessment of the ecosystem service benefits derived from the SSSI biodiversity conservation policy in England and Wales. Ecosyst. Serv. 2012, 1, 70-84. [CrossRef]

28. Bhatta, L.D.; Van Oort, B.E.H.; Rucevska, I.; Baral, H. Payment for ecosystem services: Possible instrument for managing ecosystem services in Nepal. Int. J. Biodivers. Sci. Ecosyst. Serv. Manag. 2014, 10, $289-299$. [CrossRef]

29. Wunder, S.; Angelsen, A.; Belcher, B. Forests, livelihoods, and conservation: Broadening the empirical base. World Dev. 2014, 64 (Suppl. 1), S1-S11. [CrossRef]

30. Maraseni, T.N.; Bhattarai, N.; Karky, B.S.; Cadman, T.; Timalsina, N.; Bhandari, T.S.; Apan, A.; Ma, H.O.; Rawat, R.S.; Verma, N.; et al. An assessment of governance quality for community-based forest management systems in Asia: Prioritisation of governance indicators at various scales. Land Use Policy 2019, 81, 750-761. [CrossRef]

31. Maraseni, T.N.; Neupane, P.R.; Lopez-Casero, F.; Cadman, T. An assessment of the impacts of the REDD+ pilot project on community forests user groups (CFUGs) and their community forests in Nepal. J. Environ. Manag. 2014, 136, 37-46. [CrossRef] [PubMed]

32. Paudyal, K.; Baral, H.; Lowell, K.; Keenan, R.J. Ecosystem services from community-based forestry in Nepal: Realising local and global benefits. Land Use Policy 2017, 63, 342-355. [CrossRef]

33. Rai, R.K.; Dhakal, A.; Khadayat, M.S.; Ranabhat, S. Is collaborative forest management in Nepal able to provide benefits to distantly located users? For. Policy Econ. 2017, 83, 156-161. [CrossRef]

34. Shoyama, K.; Yamagata, Y. Predicting land-use change for biodiversity conservation and climate-change mitigation and its effect on ecosystem services in a watershed in Japan. Ecosyst. Serv. 2014, 8, 25-34. [CrossRef]

35. Muhamad, D.; Okubo, S.; Harashina, K.; Parikesit; Gunawan, B.; Takeuchi, K. Living close to forests enhances people's perception of ecosystem services in a forest-agricultural landscape of West Java, Indonesia. Ecosyst. Serv. 2014, 8, 197-206. [CrossRef]

36. Government of Nepal. Emission Reductions Program Document (ER-PD); REDD Implementation Centre-REDD IC: Kathmandu, Nepal, 2019.

37. Singh, B.K. Land tenure and conservation in chure. J. For. Livelihood 2017, 15, 87-102. [CrossRef]

38. President Chure-Tarai Madhesh Conservation Development Board (PCTMCDB). President Chure-Tarai Madesh Conservation and Management Master Plan; President Chure-Tarai Madhesh Conservation Development Board (PCTMCDB): Kathmandu, Nepal, 2017.

39. President Chure-Tarai Madhesh Conservation Development Board (PCTMCDB). Landscape Inventory Characterization and Engineering Design for Mitigation of Chure Area in Ten Districts; Pesident Chure-Tarai Madesh Conservation Development Board (PCTMCDB): Kathmandu, Nepal, 2016.

40. President Chure-Tarai Madesh Conservation Development Board (PCTMCDB). Socio-Economic Impact Study of Chure Region; President Chure-Tarai Madesh Conservation Development Board (PCTMCDB): Kathmandu, Nepal, 2013.

41. Chaudhary, S.; McGregor, A.; Houston, D.; Chettri, N. Reprint of: Environmental justice and ecosystem services: A disaggregated analysis of community access to forest benefits in Nepal. Ecosyst. Serv. 2018, 29, 316-332. [CrossRef]

42. Bhattarai, B.P.; Poudyal, B.H.; Acharya, R.P.; Maraseni, T. Policy and governance issues in timber harvesting: A case study of collaborative forest in Nepal. In Proceedings of the Wild harvests, governance, and livelihoods in Asia, Kathmandu, Nepal, 30 November-2 December 2017; pp. 186-194.

43. Jhaveri, N.; Adhikari, J. Nepal Land and Natural Resource Tenure Assessment for Proposed Emission Reductions Program in the Terai Arc Landscape; USAID Tenure and Global Climate Change Program: Washington, DC, USA, 2015. 
44. Mandal, R.; Bhattarai, B. Collaborative Forest: Issues, Challenges and Possible Solutions; National Forum for Advocacy Nepal (NAFAN) \& Association of Collaborative Forest Users (ACOFUN): Kathmandu, Nepal, 2014.

45. District Forests Office. Five Year Plan of District Forest Office; District Forest Office (DFO): Sarlahi, Nepal, 2017.

46. District Development Committee (DDC). District Profiles of Sarlahi; District Development Committee: Sarlahi, Nepal, 2016; pp. 1-229.

47. District Forest Office-DFO. Annual Progress Report of DFO Sarlahi; Disrict Forest Office: Sarlahi, Nepal, 2017; pp. 1-74.

48. CFM. Phuljor Collaborative Forests Management Plan; District Forest Office: Sarlahi, Nepal, 2016; pp. 1-76.

49. Department of Plant Resources (DPR). Status Mapping and Feasibility Study for Cultivation Promotion of MAPs/NTFPs in the Chure and Adjacent Areas of Makwanpur, Bara, Parsa, Rautahat, Sarlahi, Sunsari, Morang and Jhapa Districts; Department of Plant Resources (DPR): Kathmandu, Nepal, 2014.

50. Bhandari, P.; KC, M.; Shrestha, S.; Aryal, A.; Shrestha, U.B. Assessments of ecosystem service indicators and stakeholder's willingness to pay for selected ecosystem services in the Chure region of Nepal. Appl. Geogr. 2016, 69, 25-34. [CrossRef]

51. Sharma, B.; Rasul, G.; Chettri, N. The economic value of wetland ecosystem services: Evidence from the Koshi Tappu Wildlife Reserve, Nepal. Ecosyst. Serv. 2015, 12, 84-93. [CrossRef]

52. Baral, S.; Basnyat, B.; Khanal, R.; Gauli, K. A total economic valuation of wetland ecosystem services: An evidence from Jagadishpur Ramsar Site, Nepal. Sci. World J. 2016, 2016, 1-10. [CrossRef]

53. Basnyat, B.; Sharma, B.P.; Kunwar, R.M.; Acharya, R.P.; Shrestha, J. Is current level of financing sufficient for managing protected area? Bank Jank 2012, 22, 3-10.

54. Kaplowitz, M.D.; Hoehn, J.P. Do focus groups and individual interviews reveal the same information for natural resource valuation? Ecol. Econ. 2001, 36, 237-247. [CrossRef]

55. Shoyama, K.; Yamagata, Y. Local perception of ecosystem service bundles in the Kushiro watershed, Northern Japan-Application of a public participation GIS tool. Ecosyst. Serv. Part A 2016, 22, 139-149. [CrossRef]

56. Haines-Young, R.; Potschin, M. Common International Classification of Ecosystem services (CICES) Version 4: Response to Consultation; CICES: Sale, UK, 2012.

57. Paudyal, K.; Baral, H.; Burkhard, B.; Bhandari, S.P.; Keenan, R.J. Participatory assessment and mapping of ecosystem services in a data-poor region: Case study of community-managed forests in central Nepal. Ecosyst. Serv. 2015, 13, 81-92. [CrossRef]

58. Adhikari, S.; Baral, H.; Nitschke, C. Identification, prioritization and mapping of ecosystem services in the Panchase Mountain Ecological Region of Western Nepal. Forests 2018, 9, 554. [CrossRef]

59. Sharma, R.; Rimal, B.; Baral, H.; Nehren, U.; Paudyal, K.; Sharma, S.; Rijal, S.; Ranpal, S.; Acharya, R.P.; Alenazy, A.A. Impact of land cover change on ecosystem services in a tropical forested landscape. Resources 2019, 8, 18. [CrossRef]

60. Ministry of Forests and Soil Conservation (MFSC). Nepal National Biodiversity Strategy and Action Plan 2014-2020; Government of Nepal Kathmandu: Kathmandu, Nepal, 2014.

61. Cuni-Sanchez, A.; Pfeifer, M.; Marchant, R.; Burgess, N.D. Ethnic and locational differences in ecosystem service values: Insights from the communities in forest islands in the desert. Ecosyst. Serv. 2016, 19, 42-50. [CrossRef]

62. Ahammad, R.; Stacey, N.; Sunderland, T.C.H. Use and perceived importance of forest ecosystem services in rural livelihoods of Chittagong Hill Tracts, Bangladesh. Ecosyst. Serv. 2019, 35, 87-98. [CrossRef]

63. Ministry of Forests and Soil Conservation (MFSC). Strategy and Action Plan 2015-2025: Terai Arc Landscape, Nepal; Ministry of Forests and Soil Conservation (MFSC): Kathmandu, Nepal, 2015; pp. 1-92.

64. Davies, J.; Richards, M. The Use of Economics to Assess Stakeholder Incentives in Participatory Forest Management: A Review; Overseas Development Institute: London, UK, 1999; pp. 1-55.

65. Pearce, D.W.; Turner, R.K. Economics of Natural Resources and the Environment; The Johns Hopkins University Press: Baltimore, MD, USA, 1990.

66. Maraseni, T.N.; Cockfield, G.; Apan, A. Valuing ecosystem services from forests: A multidisplinary field-based approach. In Proceedings of the IUFRO World Congress: Forests in the Balance: Linking Tradition and Technology, Brisbane, Australia, 8-13 August 2005.

67. GON. Shibeshwar Community Forest Operational Plan; District Forest Office: Sarlahi, Nepal, 2006.

68. Hartter, J. Resource use and ecosystem services in a forest park landscape. Soc. Natl. Resour. 2010, 23, 207-223. [CrossRef] 
69. Murali, R.; Redpath, S.; Mishra, C. The value of ecosystem services in the high altitude Spiti Valley, Indian Trans-Himalaya. Ecosyst. Serv. 2017, 28, 115-123. [CrossRef]

70. Neupane, P.R.; Maraseni, T.N.; Köhl, M. The sugarcane industry in Nepal: Opportunities and challenges. Environ. Dev. 2017, 24, 86-98. [CrossRef]

71. Fagerholm, N.; Käyhkö, N.; Ndumbaro, F.; Khamis, M. Community stakeholders' knowledge in landscape assessments-Mapping indicators for landscape services. Ecol. Indic. 2012, 18, 421-433. [CrossRef]

72. Joshi, J.; Bhattarai, T.N.; Sthapit, K.M.; Omura, H. Soil erosion and sediment disaster in Nepal-A review. J. Facu. Agri. Kyushu Univ. 1998, 42, 491-502.

73. Ghimire, S.; Higaki, D.; Bhattarai, T. Estimation of soil erosion rates and eroded sediment in a degraded catchment of the Siwalik Hills, Nepal. Land 2013, 2, 370-391. [CrossRef]

74. National Planning Commission (NPC). Nepal Flood 2017 Post Flood Recovery Needs Assessment; National Planning Commission (NPC): Kathmandu, Nepal, 2017.

75. Shrestha, S.; Karky, B.; Karki, S. Case study report: REDD+ pilot project in community forests in three watersheds of Nepal. Forests 2014, 5, 2425-2439. [CrossRef]

76. Acharya, D.; Khanal, D.R.; Bhattarai, H.P.; Gautam, B.; Karki, G.; Acharya, R.P.; Van Goor, W.; Trines, E. REDD Strategy of Nepal; REDD Implementation Centre (R.I.C.): Kathmandu, Nepal, 2015.

77. Orenstein, D.E.; Groner, E.; Argaman, E.; Boeken, B.; Preisler, Y.; Shachak, M.; Ungar, E.D.; Zaady, E. An ecosystem services inventory: Lessons from the northern Negev long-term social ecological research (LTSER) platform. Geogr. Res. Forum 2012, 32, 96-118.

78. Torkar, G.; Krašovec, U. Students' attitudes toward forest ecosystem services, knowledge about ecology, and direct experience with forests. Ecosyst. Serv. 2019, 37, 100916. [CrossRef]

79. Pandey, S.S.; Maraseni, T.N.; Cockfield, G. Dynamics of carbon and biodiversity under REDD+ regime: A case from Nepal. Environ. Sci. Policy 2014, 38, 272-281. [CrossRef]

80. Pandey, S.S.; Maraseni, T.N.; Cockfield, G. Carbon stock dynamics in different vegetation dominated community forests under REDD+: A case from Nepal. For. Ecol. Manag. 2014, 327, 40-47. [CrossRef]

81. Ministry of Forests and Soil Conservation. Forestry Sector Strategy (2016-2025); Ministry of Forests and Soil Conservation: Kathmandu, Nepal, 2016; pp. 1-94.

(C) 2019 by the authors. Licensee MDPI, Basel, Switzerland. This article is an open access article distributed under the terms and conditions of the Creative Commons Attribution (CC BY) license (http://creativecommons.org/licenses/by/4.0/). 